\title{
METAMORFOSE NA LITERATURA MAXAKALI
}

Charles Bicalho*

Resumo: Uma investigação sobre o processo da metamorfose presente na produção literária escrita e/ou oral dos Maxakali - também chamados tikmû'ûn - povo indígena que habita quatro territórios no estado de Minas Gerais, falam sua língua ancestral - o maxakali - e já publicaram mais de uma dezena de livros bilíngues (em maxakali e português)

PALAVRAS-CHAVE: metamorfose; literatura; Maxakali; Tikmû'ûn. *charlesbicalho@gmail.com

Doutor em Literatura Brasileira pela Faculdade de Letras da U HiMG. Pos-Doutor junto a CAPES/Ministério da Educação.

ABSTRACT: An investigation into the process of metamorphosis present in written and/or oral literary production of Maxakali indigenous people - also called tikmû'ûn - which inhabits four territories in the State of Minas Gerais in the Southeast region of Brazil, speaks its ancestral language - the maxakali - and have published more than ten bilingual books (in Portuguese and Maxakali).

KEYWORDS: metamorphosis; literature; Maxakali; Tikmû'ûn. 
1. Palavra maxakali com a qual os índios se autodenominam. Seu significado aproximado e "humanidade".

2. POPOVICH. Maxakali supernaturalism, p. 20.

3. ALVARES. Yãmîy, os espiritos do canto, p. 96.

\section{INTRO}

Os Maxakali, ou Tikmû' ûn, ${ }^{1}$ são um povo indígena de aproximadametne 1.500 indivíduos que habitam atualmente quatro territórios no estado de Minas Gerais. Tradicionalmetne caçadores e coletores, eles vagavam pela região que compreende o sul da Bahia, o norte do Espírito Santo e o nordeste de Minas Gerais. Falam sua língua ancestral, o maxakali, do tronco linguístico Macro-Gê, família Maxakali.

Até há pouco tempo exclusivamente oral, a cultura maxakali passa atualmente a agregar o registro escrito como forma de manuteção e divulgação de sua tradição. Os tikmûûn já publicaram vários livros, geralmente bilíngues (em maxakali e português), para serem usados em suas escolas. Para os livros de literatura os escritores indígenas geralmente vão buscar em suas histórias e contos tradicionais os subsídios para a escrita

Nos anos de 1960, Haroldo Popovich e sua esposa Francis Popovich, ambos ligados ao Summer Institute of Linguistics (SIL), conviveram com os Maxakali, aprenderam sua língua e estabeleceram um método de escrita baseado no alfabeto latino. Traduziram para o inglês alguns cantos e narrativas tradicionais maxakalis, bem como o Velho Testamento para a língua maxakali. Por fim, alfabetizaram alguns índios.

O propósito catequizador dos Popovich não vingou, mas a escrita se sedimentou entre os seus antigos alunos, tornando-se o meio para o registro de sua própria tradição religiosa e cultural.
Mais recentemente, no ano de 1996 inaugurou-se o Programa de Implantação de Escolas Indígenas de Minas Gerais (PIEIMG), voltado à criação de um sistema de ensino diferenciado que proporcionasse o desenvolvimento de métodos próprios de aprendizagem para as comunidades indígenas do estado. Teve início uma produção mais sistemática de livros e outros produtos, visando o desenvolvimento de material didático para as escolas nas aldeias. Livros de literatura se incluem neste rol.

Atualmente alguns professores maxakalis já se formaram em nível universitário e continuam ensinando e produzindo livros, filmes e outros.

\section{KOXUK, YÃMÎY, YÃMÎYXOP, YÃMÎYXOPTAK}

$\mathrm{Na}$ filosofia maxakali, a pessoa tem um koxuk, termo que pode ser traduzido por "alma". Para Povovich, "a alma do vivo é chamada koxuk". "Imagem", "reflexo", "sombra”, são também sentidos da palavra koxuk. Segundo Alvares, o koxuk recebe às vezes o epíteto de "palavra verdadeira": "o koxuk é a palavra. E a palavra se transformará em yãmîy e será eterna”, escreve ela. Percebe-se que o Maxakali tem na palavra ou na linguagem um elemento fundamental da formação de uma pessoa. ${ }^{4}$

Ao longo de sua vida um indivíduo maxakali deve aprender uma quantidade indeterminada mas significativa de cantos de sua tradição. Tais cantos são chamados yãmîy. A
4. Penso que seria mais adequado pensarmos em "linguagens", endo na "palavra" um eixo desconsiderar outras expressões. desconsiderar outras express Como vimos, koxuk não é apenas "palavra", mas significa também ao menos outro modo expressivo, como as imagens. Prefiro pensar no koxuk com uma essência humana, um anima; ou seja, aquilo que nos anima, que nos move: que nos faz vivos. Os cinco sentidos do corpo (que geram todas as mídias), mais o "sexto sentido" (relativo ao mistério, ao indizível) que se relaciona ao espírito, à religião, seriam, a meu ver, bons pontos de partida para considerarmos o koxuk.
EM TESE
BELO HORIZONTE
v. 19
N. 3
SET.-DEZ. 2013
BICALHO. Metamorfose na literatura maxakali
P. $11-23$ 
5. POPOVICH. Maxakali supernaturalism, p. 20

6. ALVARES. Yãmîy, os espíritos do canto, p. 82. mesma palavra designa também os entes espirituais do panteão maxakali. Geralmente tais entes são animais, plantas, e demais elementos da natureza, principalmente do bioma Mata Atlântica, vegetação típica da região onde tradicionalmente viviam. Antepassados e outros parentes mortos também se tornam espíritos yãmîy. Muitas vezes objetos também se sacralizam, como a sanfona, por exemplo, tamanho o carinho e a admiração que os tikmûûn devotam ao instrumento musical. Outro caso inusitado de yãmîyzação é o do uniforme do time de futebol maxakali. Percebe-se que para se tornar yãmîy vai depender da carga de importância e afeto que os índios devotam a determinada coisa.

Tal aprendizado de cantos, que se dá ao longo de toda a vida com os parentes, com os pajés, com os amigos, em situações as mais variadas, mas principalmente naquelas relacionadas aos rituais (yãmîyxop), é necessário para que, segundo os preceitos culturais e religiosos indígenas, a alma (koxuk) do indivíduo se torne espírito (yãmîy). "Somente após a morte do corpo é (o koxuk) chamado de yãmîy", atesta Popovich. "Este fluxo", escreve Myriam Alvares, "relaciona-se, de um lado, com o processo de transformação do Koxuk em Yãmîy - da palavra em canto - e, de outro, com o trânsito dos próprios Yãmîy".

O que nos parece é que o yãmîy é uma espécie de padrão, um modelo, uma imagem mental maxakali, em sua visão de mundo: um ideal. Tem-se a fala humana, comum, mas o canto yãmîy é supremo. Tem-se as pinturas corporais e demais enfeites humanos, mundanos, mas a indumentária yãmîy é soberba. Tem-se a vida comum do dia-a-dia, mas a experiência transcendental do yâmîyxop é o êxtase. O yãmîy é o grande modelo a ser seguido: de caráter, de beleza, de bondade, etc.

É provável que se possa decompor yãmîy em yã (que denota uma "afirmação enfática") ${ }^{7}$ e mîy (o verbo "fazer"). Yã está, por exemplo, no pronome de afirmação yãmûn, cuja expressão tradutória dada por Popovich seria: "É isso mesmo". ${ }^{8}$ Talvez seja o yã-mîy um "fazer enfático", como uma figuração do "gesto enfático" do ritual, "a luta para encontrar uma eficácia do gesto, desfazer o signo para encontrar a ação Artaud classificava-o como uma 'sobrevivência instintiva de uma magia". ${ }^{9}$ Nessa perspectiva, yãmîys seriam "personalidades nítidas, interagindo num espaço dramático”..$^{10} \mathrm{Ou}$ seja, o ritual yãmîyxop é a grande fonte de todas as formas comunicacionais ou midiáticas indígenas.

A palavra seria, portanto, um análogo, uma metonímia, de todo o complexo comunicacional, midiático, que, regido pelo yãmîy, se transforma, se elabora ao longo da vida de uma pessoa, com vistas a se tornar ela mesma, após a morte, algo bom e belo: um yãmîy. Assim, se aprendem o máximo de cantos yãmîy ao longo da vida, para que a fala, corriqueira, mundana, comum, se elabore e se transforme em canto: o koxuk se transforme em yãmîy. Do mesmo modo, se aprende a vestimenta
7. POPOVICH. Dicionário MaxakalíPortuguês/Glossário PortuguêsMaxakali, p. 85.

8. POPOVICH. Dicionário MaxakaliPortuguês/Glossário PortuguêsMaxakali, p. 85.

9. EINAUDI, p. 27.

10. PAGLIA, Personas sexuais, p. 77. 
dos yãmîy, suas comidas preferidas, suas danças, enfim, tudo sobre eles. Quanto mais se sabe sobre eles, mais se é respeitado na comunidade maxakali. No auge, a pessoa se torna um pajé. Um yãmîyxoptak. Literalmente, um "pai de ritual", ou um mestre de cerimônia, um coordenador de congresso, aquele que sabe organizar um grande encontro de espíritos, que é o que é um yãmîyxop. Esta palavra agrega yãmîy ("espírito"), mais xop, uma particular que significa "grupo", "encontro", "coletivo", "quantidade": o ritual é então um encontro de espíritos, um congresso transcendental. Em yãmîyxoptak tem-se o acréscimo de tak, que significa "pai", "mestre". O pajé é o mestre desses encontros. É ele quem sabe em profundidade qual é a indumentária do grupo de yãmîys que vem visitar a aldeia. Qual a comida preferida do yãmîy. Qual sua coreografia. Se ele gosta de fumar. Quais são seus cantos (e o pajé deve saber uma série deles). Enfim, toda a dinâmica de um ritual, que é um complexo de semioses, envolvendo várias linguagens, deve ser coordenado pelo pajé. De tais semioses fazem parte também as narrativas tradicionais, conectadas àquilo a que chamamos mitologia. O yãmâyxop é uma festa, um festival, um espetáculo, uma congregação, uma comunhão, uma comemoração. E o yãmîyxoptak é o seu mestre organizador.

O yãmîy pressupõe portanto uma grande transformação, ou várias: da linguagem comum em linguagem ritual (os yãmîys e seus cantos se dão em língua ritual, uma variação dialetal da língua maxakali repleta de termos herméticos, que demandam certa dedicação ao universo espiritual para ser dominado); da comida do dia-a-dia em ricos banquetes; da vestimenta comum para a indumentária dos espíritos. Enfim, toda a aldeia e seus habitantes se transformam para o yãmîyxop. De certa forma, esses rituais são um resumo, uma encenação ou representação, ou uma experimentação de vivência, daquilo que é uma ideia geral e comum do que é a vida para um tikmûûn. Ou da vida como um processo de transformação, de transcendência e elevação.

Essa modalidade de transformação entre os tikmûûun está relacionada a toda a trajetória de vida. Como escreve Myriam Alvares, está intimamente ligada ao processo de transformação do koxuk em yãmîy: "A noção de palavra se eleva como possibilidade de se transcender a este limite, ou seja, de colocar a morte não mais como um fim, mas como um processo de transformação".

\section{INMÕX̃̃}

O contrário do yãmîy seria Inmõxã. Trata-se de uma fera canibal que tem o corpo humanoide, mas que pode metamorfosear-se em felinos, principalmente a onça (hãngãy), e caçar humanos na mata. Quem, de acordo com a tradição maxakali, não aprender a ser yãmîy ao longo da vida, se tornará Inmõxã após a morte, o grande inimigo dos humanos.
11. ALVARES. Yãmîy, os espíritos do canto, p. 77. 
12. BICALHO. Narrativas orais maxakalis, p. 74.
Este, ao contrário do yãmîy, que é festejado a cada ritual yãmîyxop, deve ser morto transpassando-se com lança ou flecha um dos orifícios de seu corpo (olho, boca, umbigo, ânus), já que sua pele é intransponível. Aqueles que, não seguindo os preceitos da religião maxakali, não aprenderam cantos yãmîy ao longo da vida e, portanto, não estando aptos a se tornarem eles mesmos yãmîy após a morte, se tornarão Inmõxã. Como escrevi em outra ocasião:

Dentro da cultura Maxakali, Inmõxã é tido como uma espécie de demônio. Aquele que não cumprir os preceitos religiosos, as regras de convivência entre os membros da sociedade, vai pagar após a morte se transformando no monstro. Muito semelhante à concepção cristã, o infrator não terá a alma (koxuk em Maxakali) elevada à categoria de yãmîy, e será condenado a vagar sozinho na mata à procura de alguém para devorar. ${ }^{12}$

Se uma onça é um animal feroz, alguém muito raivoso também se deve temer e evitar. Um ser humano vira onça quando se torna enraivecido. É o que se dá com Inmõxã. Neste caso, não à toa a palavra para "raiva" está na raiz de "onça” em maxakali. Hãngãy (o animal) agrega gãy (feroz, nervoso, raivoso, irritado).

Nesta metamorfose de Inmõxã a imagem se altera. Onde antes se via uma pessoa, agora se vê uma onça, um vez que Inmõxã é a própria encarnação da ferocidade. A metamorfose

EM TESE

BELO HORIZONTE

v. 19

N. 3

SET.-DEZ. 2013 parece servir à representação das transformações do espírito. Um ser humano "vira onça" quando fica enraivecido. Os Maxakali parecem querer dizer (e o fazem), não retoricamente, mas mostrando em imagens, tal transformação. Como diz Nietzsche, "a metáfora não é, para o verdadeiro poeta, uma figura de retórica, mas uma imagem substituída que plana realmente diante de seus olhos em lugar de um conceito". ${ }^{13}$

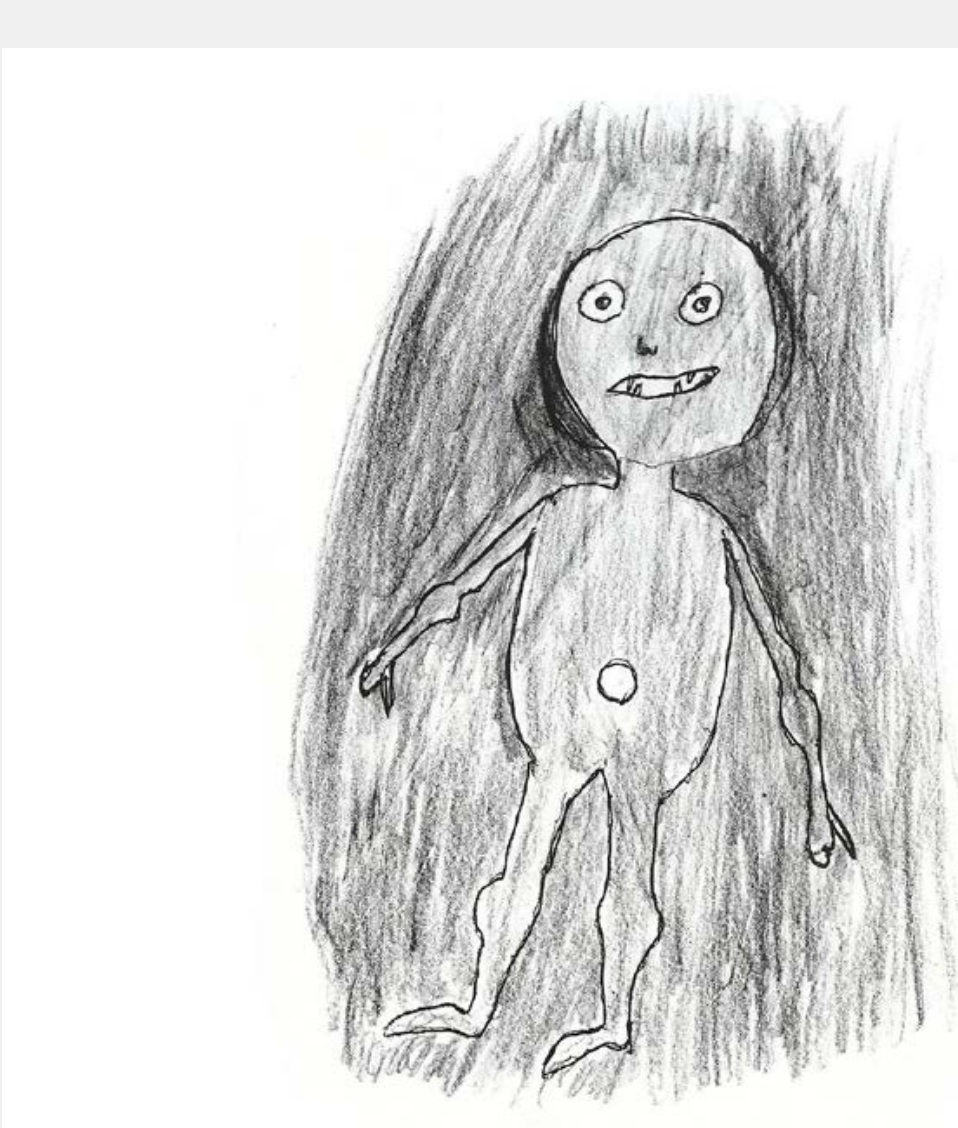

FIGURA 1
13. NIETZSCHE. O nascimento da tragédia, p. 65.

FIGURA 1

Desenho representando Inmõxã para o livro Hitupmã'ax/Curar (2008), p. 157. 
14. Quando um falecido é enterrado e sua sepultura aparece erodida rachada, e sinal de que ele se transformou é minoxá. Para anular o mal, é necessário corpo.

15. BICALHO. Narrativas orais maxakali, p. 74. O texto é uma transcrição da gravação da fala de Zezinho.
É asim que os Maxakali transfiguram a morte em Inmõxã. Quando se encontra com Inmõxã é o mesmo que estar se encontrando com a própria morte. Daí o pavor que provoca tal encontro.

Zezinho Maxakali certa vez, ao narrar-me uma das histórias de Inmõxã, deu uma descrição que mostra a associação entre a imagem da fera maxakali e a de um cadáver em decomposição. Ele conta que certa vez ele e alguns parentes foram ao cemitério com o propósito de desenterrar um Inmõxã. ${ }^{14}$ Zezinho descreve o que viu quando ele e seus parentes reviraram a cova:

E'tava... ele... virou tudo

Esse couro aqui saiu, ficou outro.

Aqui ficou... O olho... Num tinha dente.

Aí foi cavando, cavando.

Aí descobriu, ele 'tava encostado, sentado assim ó. Sentado. ${ }^{15}$

Inmõxã é a imagem do horror da morte. Suas feições, como descritas por Zezinho, se confundem com a do próprio cadáver em decomposição. Algo semelhante nos dá Ovídio, por exemplo, ao descrever a inveja, sentimento normalmente não tido em boa conta pela moral ocidental, e por isso pintado em cores monstruosas pelo poeta latino em "A gruta da inveja", presente nas suas Metamorfoses:

\section{É a estância da Inveja em gruta enorme,}

Lá nuns profundos vales escondida,
Aonde o Sol não vai, nem vai Favônio.

Reina ali rigoroso, eterno frio,

De úmidas, grossas névoas sempre abunda.

O monstro vive de vipéreas carnes,

Dos seus tartáreos vícios alimento.

Da morte a palidez lhe está no aspecto,

Magreza, e corrupção nos membros todos;

Olha sempre ao revés; ferrugem torpe

Nos asquerosos dentes lhe negreja;

Vê-se o fel verdejar no peito imundo,

Espumoso veneno a língua verte... ${ }^{16}$

\section{SÉRIE, SEQUÊNCIA}

A morte-metamorfose tikmûûn é um devir. E, muitas vezes, um devir-animal. E como escrevem Deleuze \& Guattari "Num devir-animal, estamos sempre lidando com uma matilha, um bando, uma população, um povoamento, em suma, com uma multiplicidade". ${ }^{17}$ De fato, o yãmîyxop maxakali é composto de uma série. O morcego (xûnîn), por exemplo, pode tomar a forma da lua (mãyõnhex), do sol (mãyõn), da estrela (mãyõnnãg), da anta (ãmãxux), da cobra (kãyã), do sapo (konnokaxax), do jacaré (mããa), da onça (hãmgãy), do cavalo (kamanok), da irara (kupûmõg), de Inmõxã, do ãyuhuk, ${ }^{18}$ ou até do helicóptero (mîmptutmõg pepi mõg). Sua sequência pode ser vista inclusive nos desenhos ao longo do mîmãnãm. ${ }^{19}$
16. OVIDIO. Metamorfoses, p. 45.

17. DELEUZE \& GUATTARI. Mi platôs, p. 19.

18. Termo em língua maxakali que designa os não-indígenas.

19. Nome que se dá ao “pau de religião" maxakali. "Poste sagrado", trata-se de um tronco de árvore tradicionalmente pintado com urucum (atualmente usam-se tambem tintas industriais), com grafismos e uma serie de desenhos que demonstra a sequência de transformações do yãmîy. 
FIGURA 2

Foto de um mîmãnãm, o "pau de religião", do morcego.

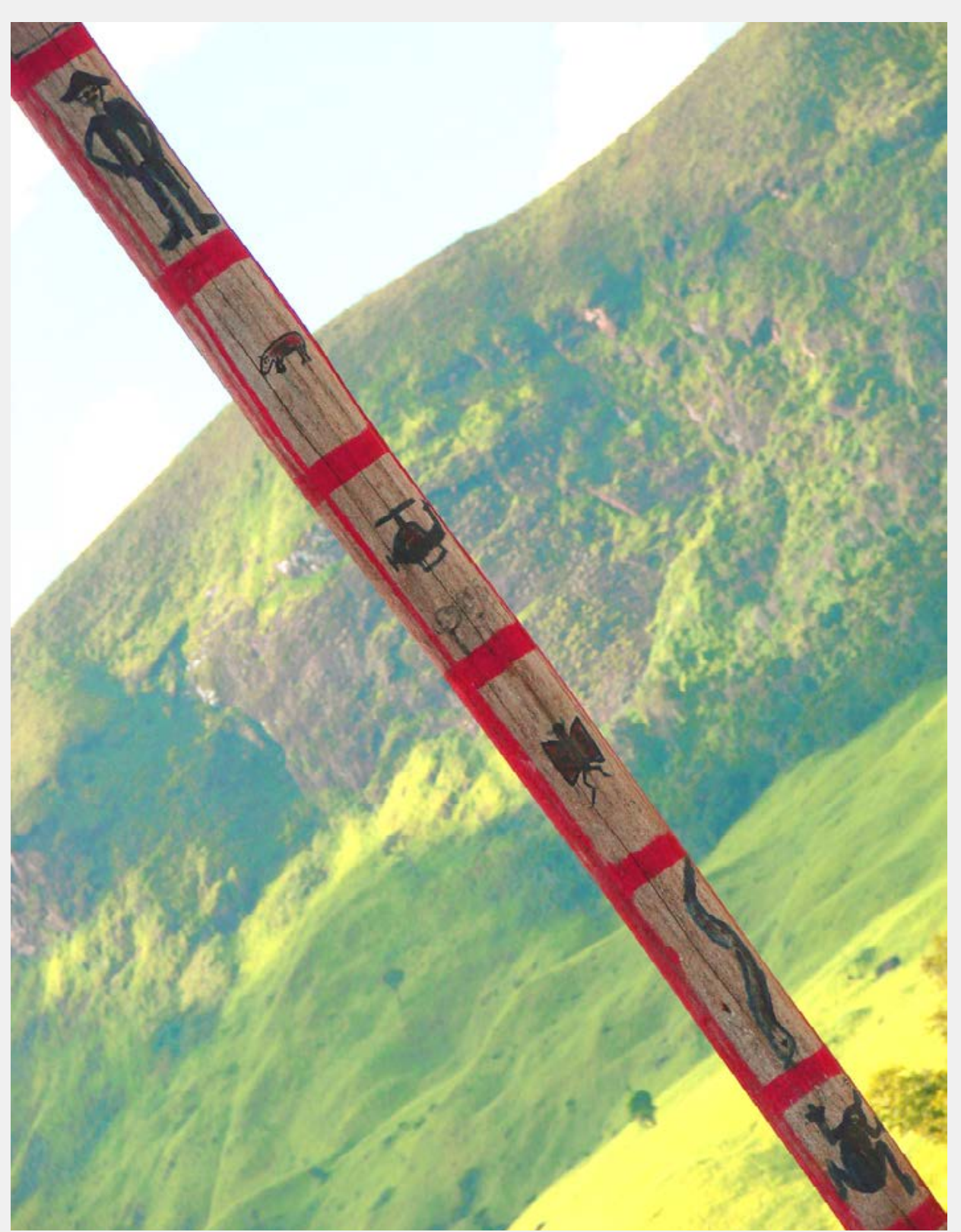

FIGURA 2
Estes que compõem a série, por sua vez, se tornam os narradores nos yãmîyxop. Analogias podem ser feitas com a ópera ou com o teatro. "Personagens" encenam uma história e contam essa história cantando. Cada yãmîy é responsável por transmitir uma determinada passagem da história. São eles os responsáveis por garantir a reprodução daquilo que costuma ser chamado de mitologia, mas que se confunde com a própria literatura: miteratura.$^{20} \mathrm{O}$ animal, portanto, que "encabeça" um yãmîyxop tem a capacidade de ser muitos, de se metamorfosear em vários narradores. "Dizemos que todo animal é antes um bando, uma matilha." ${ }^{21}$ Evoco aqui certa analogia com os heterônimos de Fernando Pessoa: cada persona-escritor com seu próprio estilo e personalidade.

O yãmîy Moka’ok, o "espírito-corredor”, se transforma em amãxux (anta), putuxkup (coruja), nãhãn (urucum), kãyãta xeka (cobra grande), putixnãg (sobrinhos), mõgmõka (gavião) e outros. E é sobre esses devires que os professores maxakalis escrevem em seus livros. Penso que os professores indígenas que escrevem os livros desempenham a função de escribas, sendo os escritores os próprios yãmîys. Estes seriam escritores orais, que, para sua escrita, fazem uso de todo tipo de grafia: o canto, a dança (coreografia), a culinária (cada yãmîy tem seu prato preferido), o figurino (cada yãmîy tem sua indumentária específica, pintura corporal, adornos, etc.). Os professores escritores indígenas tentam traduzir em seus
20. O neologismo "miteratura" denotaria o momento, como o que têm vivido os Maxakali, em que os agentes culturais de uma determinada comunidade tradicionalmente ágrafa, se põem a fazer uso do arcabouço mitológico de sua tradição, para iniciar o registro pela escrita. Trata-se da arte verbal que está entre a mitologia e a literatura, entre um estado primordial e a modernidade.

21. DELEUZE \& GUATTARI. Mil platôs, p. 20. 
22. DELEUZE \& GUATTARI. Mil platôs, p. 21.

23. POPOVICH. Dicionário MaxakalíPortuguês/Glossário PortuguêsMaxakali, p. 86. livros (que são ricamente ilustrados) essa profusão midiática dos yãmîys e seus yãmîyxops.

São, pois, esses devires-escritores-yãmîy que deixam seus rastros pelas mãos dos escritores-professores Tikmû'ûn quando estes se põem a produzir livros. Neste caso, escrita e magia, ou feitiçaria, estariam intimamente conectados:

Se o escritor é um feiticeiro é porque escrever é um devir, escrever é atravessado por estranhos devires que não são devires-escritores, mas devires-rato, devires-inseto, devires-lobo, etc. [...] O escritor é um feiticeiro porque vive o animal como a única população perante a qual ele é responsável de direito. ${ }^{22}$

\section{YÃYHÃ}

Em língua maxakali poderíamos usar o termo yãyhã como equivalente para "metamorfose", donde yãy é uma partícula que indica reflexividade, como o "se" em português, e hã, um modificador, cujo sentido aproximado seria "por meio de". "Transformar em algo" é a tradução que nos dá Popovich, ${ }^{23}$ podendo ser sintetizada em "modificar-se" ou "transformar-se".

Em “Mãtãnãg”, história cuja versão em português ganhou o título de "Encantada", temos um dos mais emblemáticos exemplos de metamorfose na literatura maxakali. Fragmentária, sabemos que ela ocorre pela mudança das pegadas ou rastros observados no chão por Mãtãnãg:
No outro dia, ela levantou bem cedinho e foi seguir as pegadas, olhar. Na cinza da estrada tinha o rastro de um ratinho. Um rato. Aí, ela seguiu em frente e viu um rastro de gato. Um gato. Ela foi, seguiu, seguiu... Lá na frente, ela viu um rastro de raposa. Uma raposa. Lá na frente. Então, ela foi atrás e viu um pé de hãngãy (onça). Ela foi, foi seguindo... o rastro foi aumentando. $\mathrm{O}$ rastro de onça. Ela foi atrás, foi atrás correndo... e deixou seu kutok (filho) em casa. Deixou o menino na casa e foi correndo,

correndo...

Lá na frente, o rastro mudou: era um pé de tihik (gente). Já era um pé de gente. ${ }^{24}$

A transformação descrita é do espírito do marido de Mãtãnãg, seu yãmîy. Após ser picado por uma cobra, ele morre. Em sua caminhada rumo ao hãmnõgnõy (a morada dos yãmîys), seu espírito se transforma em rato, gato, raposa, onça, e finalmente homem. Indicial, metonímica, a metamorfose é sugerida pelas pegadas, exemplo semiótico clássico para índice.

Esta nos faz lembrar de outra famosa metamorfose, também indicial, percebida pela linguagem: de "Meu tio, Iauareté”, o conto de Guimarães Rosa. Como um reverso da metamorfose em Mãtãnãg (de animal para homem), no conto de Rosa dá-se o contrário: o homem vai virando onça.
24. MAXAKALI. Hitupmã̃ãx/Curar p. 36. 
25. MAXAKALI. Penãhã, p. 22.

26. MAXAKALI. Penãhã, p. 22.

27. MAXAKALI. Penãhã, p. 55. 28. MAXAKALI. Penãhã, p. 57.

29. MAXAKALI. Penãhã, p. 57.
A transformação é percebida através dos elementos linguísticos que passam a fazer parte do discurso do personagem. A linguagem vai ganhando cada vez mais elementos da língua nheengatu, idioma dos índios Tupi, fazendo com que a sonoridade vá de um tom mais discursivo, passando por falas cada vez menos articuladas, até se aproximar de grunhidos, como um sinal de que o contador vai se transformando em animal totêmico deste povo: a onça.

Na história que dá nome ao livro Penãhã (2005), após os Inmõxãs (gato, onça e outros) terem comido uma tartaruga, restam as tripas desta para um último Inmõxã, que chegara atrasado ao banquete. Em meio às tripas havia um filhote da tartaruga, ainda vivo. O Inmõxã pegou o filhote e o jogou no fogo, mas ele "caiu do outro lado. Longe do fogo". ${ }^{25} \mathrm{Em}$ seguida: "Quando ele jogou o filhote, viu que não era como filhote de tartaruga, era como gente: tinha braço, perna, cabeça. E eram dois". ${ }^{26}$ Tem-se, portanto, uma mutação seguida de duplicação.

Em "'Uxape xop kik tute", ou "Ele matou os companheiros", ${ }^{27}$ os índios foram caçar capivara (kuxakuk). "Quando chegaram à beira do rio, os índios viraram kuxakuk." ${ }^{28} \mathrm{~A}$ mesma metamorfose se dá outra vez na mesma história, com outro grupo que fora ao rio caçar capivara. "Ao chegar no rio, o baixinho fez todos eles virarem capivaras." ${ }^{29}$ Neste caso é mencionado um agente que realiza a transformação, não ficando explícito tratar-se de um feiticeiro. Na versão da mesma história publicada nO Livro que conta histórias de antigamente (1998), intitulada "Nûhû kõnak yõk xokxop ãktux", ou "História dos bichos da água", fica claro tratar-se de um feiticeiro: "Os antepassados estavam caçando capivara. Um velho foi caçar junto com os seus parentes. Este velho era um feiticeiro e transformou os parentes em capivaras". ${ }^{30}$

Em “Ûhãm kãyã tep top”, ou "Estava trabalhando e a cobra matou" - ${ }^{31}$ outra história presente em Penãhã - a metamorfose se dá em casais. "Chamaram as mulheres e foram para o rio. Lá, cada homem pegou uma mulher pela mão, pulou dentro d'água e foram se transformando em casais de capivara." ${ }^{2}$

No último conto do livro Penãhã, intitulado "Xokixxeka yõg hãm ãgtux", ou "História do Tamanduá", tem-se a metamorfose de todos os personagens. Primeiro, dois filhos da índia. Eles pedem que o irmão mais novo busque folhas de pacova, para fazer penas com elas. Eles as prendem em seus braços "e começam a voar para o céu". "Os filhos se transformaram em urubus-rei e urubus comuns." ${ }^{33}$ Em seguida, foi a vez do irmão mais novo. Um de seus irmãos mais velhos diz: "Então você vai tirar um pedaço de madeira vermelha e fazer com ele um bico pra você. Tire também folhas pequenas de árvore para fazer penas com elas, assim você vai virar inhambu" ${ }^{34}$ Por fim a história mostra como o tamanduá surgiu da mulher:
30. MAXAKALI. O livro que conta hisórias de antigamente, p. 41.

31. MAXAKALI. Penãhã, p. 69.

32. MAXAKALI. Penãhã, pp. 69-70.

33. MAXAKALI. Penãhã, p. 122.

34. MAXAKALI. Penãhã, p. 122. 
35. MAXAKALI. Penãhã, p. 124. Percebe-se o mecanismo da rima visual, típica tanto da linguagem poética quanto do "pensamento selvagem" de Lévi-Strauss. Trata-se da lógica concreta e visualista da bricolagem, que vê associações entre coisas à primeira vista inconciliáveis e que permanece viva na arte de um modo geral, como na antropofagia modernisma, no ready-made duchampiano, no ideograma haroldiano, nas associações inusitadas do surrealismo, entre outros.

36. MEDEIROS. Sexo vegetal, p. 10.

37. MAXAKALI. Penãhã, p. 53.
A mãe ficou olhando tudo aquilo e pensou em virar bicho para sumir também. Ela pegou então uma folha de coqueiro e enfiou seu talo no ânus até esticar sua cabeça, de forma que ela ficasse comprida como a do tamanduá. A parte da folha que sobrou para fora se tornou seu rabo. Ela então cantou: prü, prü, prü e sumiu no mato. ${ }^{35}$

Trata-se de uma passagem sugestiva no que se refere ao conceito de "sexo vegetal", como apresentado por Sérgio Medeiros em sua obra de mesmo título. Em suas palavras, "sexo vegetal" são "vários momentos mínimos de apropriação libidinosa das árvores brasileiras", ou "uma contiguida de intensa, não necessariamente uma cópula, um ato sexual consumado ou perverso" ${ }^{36}$

Em "Konãg xeka" ou "A grande água”, a versão do dilúvio maxakali, presente em Penãhã e também nO livro que conta histórias de antigamente, $\mathrm{o}$ antepassado se une a uma macaca, depois uma porca-do-mato, e por fim a uma corsa, para enfim recomeçar a geração de humanos. O antepassado segue a sugestão do espírito yãmîy que o salvara do afogamento: "Quando foi de noite, o espírito falou pra ele procurar um bicho fêmea e casar com ele. Qualquer bicho". ${ }^{37}$ Da união com a macaca nasce um macaco, que é morto pelo antepassado. Da união com a porca-do-mato nasce um porquinho, que também é morto Só na terceira união, com a corsa, é que nasce um "maxakali de verdade", e então "ele ficou com ela para sempre". ${ }^{38}$

\section{GERAÇÕES OU DEGENERAÇÕES}

A união entre seres humanos e outros animais ou plantas tem certa recorrência nas histórias tikmûûn. Em "Õm tix nom mõnãyxop yã hapax" ou "Dois antepassados que estavam deitados", ${ }^{39}$ por exemplo, o maxakali se une e constitui família com uma estrela. Outras uniões que entram em choque com os parâmetros de nossa moral ocidental são ilustradas pela índia que mantinha relações sexuais com o genro em "Yãy hã hup tu xok" (traduzida por "A história da antepassada que ficou com vergonha") e que, diante do corpo morto da filha, que se suicida ao descobrir a relação incestuosa, diz: "Então, já que você morreu, eu vou ficar no seu lugar. Vou casar com seu marido". ${ }^{40}$

Um pouco menos estranha talvez seja a união dos meninos da aldeia, trocados entre as mães que estavam sem marido, com essas mulheres mais velhas da comunidade em "Kakxop pahokxop" ou "As crianças cegas". ${ }^{41}$ Provavelmente mais chocante é o fato de as crianças, ao final, matarem todos os homens (os pais) que haviam retornado à aldeia depois de anos, permanecendo assim com as "mães"-concubinas.

Pode parecer bizarra também a cena da antepassada que aprecia "os testículos grandes e gostosos" de anta, e que se masturba usando o pênis seco e pintado de urucum do mesmo animal em "A história do tamanduá" 42
39. MAXAKALL Penãhã, p. 91

40. MAXAKALI. Penãhã, p. 88

41. MAXAKALI. Penãhã, p. 29
EM TESE
BELO HORIZONTE
v. 19
N. 3
SET.-DEZ. 2013
BICALHO. Metamorfose na literatura maxakali
P. $11-23$ 
A lógica da metamorfose gerada por uniões estranhas é afim à do "pensamento selvagem", como formulado por Lévi-Strauss, assim como ao ideograma, em que coisas aparentemente estranhas se unem na formação de conceitos novos. Como espécies de ready-made duchampianos, os casais das histórias maxakalis citados aqui congregam seres que, em princípio, estariam em categorias diferentes e repulsivas. Porém, a lógica regente neste caso não é excludente. Pelo contrário, prevê a inclusão de qualquer elemento em suas criações, por mais alienígena que possa parecer. Os produtos dessas uniões pressupõem, por outro lado, que o espírito de seus "leitores" sejam abertos a novas interpretações.

Tal lógica, em princípio, bizarra em seu primitivismo, no entanto, se encontra com outra, ultra-moderna, a da mutação, seja acidental ou programada, promulgada pela ciência atual da engenharia genética, que prevê, e em alguns casos já realiza, a criação de, por exemplo, animais fluorescentes, ratos com orelhas humanas acopladas às suas costas e outras bizarrices que parecem criações de uma mente surrealista.

A tradição filosófica ameríndia seria desta forma uma segunda via ao logocentrismo; estando suas marcas já em sua mitologia, nisto não diferindo da tradição dita ocidental. De fato, como nos faz notar Krupat (2003) as histórias de trickster [...] não operam de acordo com a lógica opositiva que tem caracterizado o pensamento do ocidente moderno e letrado. Mais uma vez, Barre Toelken, em seu trabalho com o narrador Coquelle, George Wasson, captura bem a natureza complementar, conjuntural ou dialética das narrativas de trickster quando ele nota que para aqueles que contam as histórias, seus aspectos de bufão-benfeitor, sacro-profano não existem como oposições ou contradições. Pelo contrário as histórias insistem que 'bom e mau, sagrado e secular, esperto e burro, não são qualidades mutuamente excludentes, mas justapostas, dependende uma dos aspectos da outra. ${ }^{43}$

Como diz Viveiros de Castro citando Deleuze, é como "fazer passar uma linha de fuga entre os dois polos de uma contradição, cortá-la no meio e sair do outro lado. É como dar o pulo do gato, em outras palavras, dar o pulo da onça". ${ }^{44}$

\section{CONCLUSÃO}

Se a imagem, em sentido amplo que lhe dá Derrida - de arte, tekhné - já é em si um suplemento à natureza, e indiscutivelmente são os índios dotados dela, podemos ver a metamorfose como um suplemento ao suplemento. Podemos vê-la como um signo dotado de cumulação, de excesso ou "plenitude enriquecendo uma outra plenitude". Um signo que "se acrescenta senão para substituir". ${ }^{45}$
43. KRUPAT. Para entender os trickster tales dos nativos americanos, p. 32.

44. CASTRO. “Outro destino", p. 24

45. DERRIDA. Gramatologia, p. 178 
Se qualquer imagem é já um suplemento da natureza, e sendo a natureza um signo, invertendo-se e tomando o signo (suplemento) da natureza, podemos pensar na metamorfose como um signo "suplementado". Ou seja, um signo que tem já outra presença dentro de si.

Pois, o conceito de suplemento - que aqui determina o de imagem representativa - abriga nele duas significações cuja coabitação é tão estranha quanto necessária. $\mathrm{O}$ suplemento acrescenta-se, é um excesso, uma plenitude enriquecendo uma outra plenitude, a culminação da presença. Ele cumula e acumula presença. É assim que a arte, a tekhné, a imagem a representação, a convenção etc., vem como suplemento da natureza e são ricas de toda esta função de culminação. ${ }^{46}$

Seria a metamorfose uma metáfora visceral? Uma metáfora em outro grau? O que quisera Kafka demostrar com a imagem do inseto em que havia se transformado seu personagem Gregor Samsa?

A metamorfose é uma subversão da "força de lei" que define a significação dos signos inscritos no domínio da terceiridade (Peirce), os símbolos. Talvez mais radicalmente que a metáfora, ela rompe com a relação de convenção típica dos signos simbólicos. Sabe-se que o fenômeno é frequente, de um modo geral, nas tradições ameríndias. Para Viveiros de Castro "a metamorfose corporal é a contrapartida ameríndia do tema europeu da conversão espiritual". ${ }^{47}$ Relativamente à literatura indígena, Maria Inês de Almeida levanta a questão: "Mas e se, ao invés da metáfora, pensarmos na metamorfose como princípio da literalidade?" 48

A metamorfose é certamente um procedimento da poética tikmû'ûn, tão natural quanto o são a metáfora, a metonímia a comparação, etc. Um canto se transforma em outro, assim como os animais que eles convocam, assim como seus espíritos, assim como a vida e tudo que nela se transforma.

\section{REFERÊNCIAS}

ALMEIDA, M. I. de. Desocidentada: experiência literária em terra indígena. Belo Horizonte: Editora UFMG, 2009.

ALVARES, Myriam Martins. Yãmîy, os espíritos do canto - a construção da pessoa na sociedade Maxakali. Dissertação de mestrado apresentada ao Depto. de Antropologia Socia do Instituto de Filosofia e Ciências Humanas da Universidade stadual de Campinas como requisito para a obtenção do título de Mestre em Antropologia. Campinas, 1986.

\section{BICALHO Charles. A. P. Narrativas orais maxakalis - uma}

proposta de transcrição e análise. Dissertação de mestrado junto ao Departamento de Espanhol e Português da Universidade do Novo México. Albuquerque, Novo México, EUA: julho de 2004.

CASTRO, Eduardo Viveiros de. Araweté: os deuses canibais. Rio de Janeiro: Jorge Zahar Ed., 1986.
47. CASTRO. Arawete: os deuses canibais, p. 390.

48. ALMEIDA. Desocidentada, p. 54. 
"Outro destino." Entrevista concedida a Maria Inês de Almeida. In: Aletria - Revista de estudos de literatura do Programa de Pós Graduação em Estudos Literários (FALE/UFMG) vol. 16, jul-dez de 2007. (pp 20-36)

DELEUZE, Gilles \& GUATTARI, Fêlix. Mil Platôs - capitalismo e esquizofrenia. Vol. 04. Coordenação da tradução: Ana Lúcia de Oliveira. São Paulo: Editora 34, 1997.

DERRIDA, Jacques. Gramatologia. Tradução de Miriam

Chnaiderman e Renato Janine Ribeiro. São Paulo: Perspectiva, 2004

EINAUDI Enciclopédia. Oral/Escrito, Argumentação. V. 11 Portugal: Imprensa Nacional - Casa da Moeda, 1987.

KRUPAT, Arnold. "Para entender os trickster tales dos nativos americanos". In: SANTOS, Eloina Prati dos (org.) Perspectivas da literatura ameríndia no Brasil, Estados Unidos e Canadá. Feira de Santana: Universidade Estadual da Feira de Santana, 2003.

\section{MAXAKALI, Povo. Mõnãyxop 'ãgtux yõg tappet/O livro que} conta histórias de antigamente. Belo Horizonte: Secretaria Estadual de Educação de Minas Gerais-SEE/MG/Brasília: MEC,1998.

MAXAKALI, Povo. Penãhã - livro de Pradinho e Água Boa. Belo Horizonte: Faculdade de Letras da UFMG/CGEEI/SECAD/MEC. 2005

MAXAKALI, Povo. Hitupmã'ax/Curar. Belo Horizonte: Faculdade de Letras/UFMG; Edições Cipó Voador, 2008.
MEDEIROS, Sérgio. Sexo vegetal. PDF baixado em 24 de fevereiro de 2010 em http://www.centopeia.net/download/sexo vegetal.pdf.

NIETZSCHE, Friedrich. O nascimento da tragédia. Tradução de Antonio Carlos Braga. São Paulo: Ed. Escala, 2007. (Coleção Grandes Obras do Pensamento Universal - 73)

OVÍDIO. Metamorfoses. Excertos traduzidos por Bocage. São Paulo: Martin Claret, 2003

PEIRCE, C. S. Semiótica. $3^{a}$ ed. Tradução: José Teixeira Coelho Neto. São Paulo: Perspectiva, 2005. (Coleção Estudos Semiótica)

PAGLIA, Camille. Personas sexuais - arte e decadência de Nefertite a Emily Dickinson. Tradução de Marcos Santarrita. $3^{a}$ impressão. São Paulo: Companhia das Letras, 1992.

POPOVICH, A. Harold. Maxakali Supernaturalism. Comunicação ao Summer Institute of Linguistics, 1976. (mimeo)

\section{\& POPOVICH, Francis B. Dicionario Maxakalí-Português/} Glossario Português- Maxakali. Primeira Edição Online. Sociedade Internacional de Linguistica (SIL). Cuiabá, MT: dezembro de 2005. 